\title{
METAL-INDUCED ASTHMA \\ AND CHEST X-RAY CHANGES IN WELDERS
}

TOMASZ WITTCZAK ${ }^{1}$, WOJCIECH DUDEK ${ }^{2}$, JOLANTA WALUSIAK-SKORUPA ${ }^{2}$, DOMINIKA ŚWIERCZYŃSKA-MACHURA ${ }^{2}$, WOJCIECH CADER ${ }^{3}$, MONIKA KOWALCZYK ${ }^{1}$, and CEZARY PAŁCZYŃSKI ${ }^{1,2}$

\author{
${ }^{1}$ Nofer Institute of Occupational Medicine, Łódź, Poland \\ Department of Occupational Diseases and Toxicology \\ ${ }^{2}$ Nofer Institute of Occupational Medicine, Łódź, Poland \\ Centre of Occupational Allergy and Environmental Health \\ ${ }^{3}$ PROF MED Outpatient Clinic, Włocławek, Poland
}

\begin{abstract}
Objectives: The aim of this study was to evaluate the coexisting factors and usefulness of diagnostic methods in metal-induced asthma in Polish welders. Materials and Methods: Examination of 50 welders occupationally exposed to metals and with suspicion of metal-induced asthma (group A), 100 welders occupationally exposed to metals but without suspicion of metal-induced asthma (group B), and two control groups (10 patients with atopic asthma and 10 healthy subjects) was carried out. Questionnaire survey, clinical examination, skin prick tests to common aeroallergens and metal salts, rest spirometry tests, X-ray, metacholine challenge and a single-blind, placebo controlled specific inhalation challenge tests with metals (or work-like conditions challenge tests) were performed. Results: In group A - in 9 cases we obtained positive results of specific inhalation challenge tests with metals (in 3 cases with nickel, in 4 cases with chromium, in 1 case with cobalt and in 1 case with manganese). Nine cases of metal-induced occupational asthma were recognized. In group B - only in one case we obtained positive results of work-like conditions challenge test (clinical and spirometry changes, eosinophil influx in induced sputum), which confirmed the diagnosis of occupational asthma. In most of examined welders (62\%), pulmonary changes in chest X-ray images were noted. The statistical analysis revealed that working as a welder for more than 10 years is the coexisting factor of presence of chest $\mathrm{X}$-ray changes ( $\mathrm{p}$ - or q-type nodular changes or interstitial changes). Positive results of skin prick tests with metal salts were the coexisting factors of occupational asthma due to metals among examined group of welders. Conclusions: Specific inhalation challenge plays the key role in diagnostics of metal-induced asthma in welders. Pulmonary changes in chest X-ray were found in a significant percentage of examined welders.
\end{abstract}

Key words:

Welders, Metals, Occupational asthma, Chest X-ray changes

\section{INTRODUCTION}

Welders are exposed to fumes containing different gases and particles, depending on the composition of the welding electrodes, welded material and the welding method used. The emissions from welding processes may comprise many harmful agents, including toxic or irritant substances and asthmogens [1-3].
Welders are the group at risk of developing various respiratory signs and symptoms. Health effects associated with welding process comprise different lung function abnormalities, including metal fume fever, chronic obstructive pulmonary disease, pneumoconiosis and other interstitial pulmonary diseases (chronic beryllium disease, cobalt lung), and lung cancer [4-6]. Welders are also at risk of developing

Received: October 26, 2011. Accepted: March 23, 2012

Adress reprint requests to T. Wittczak, Department of Occupational Diseases and Toxicology, Nofer Institute of Occupational Medicine, św. Teresy 8, 91-348 Łódź, Poland (e-mail: tomekwit@imp.lodz.pl). 
occupational asthma, including allergic and non-allergic (irritant-induced) asthma. The allergic asthma appears after a latency period and in some cases IgE mediated mechanism can be identified. Welders are exposed to different asthmogens, such as: metals, diisocyanates, acrylates, acid anhydrides; however, metals and their salts should be taken into consideration as the most important allergens. Asthmogenic properties of nickel, chromium, cobalt, vanadium, manganese have been proved [2,7-11]. But the pathophysiological mechanisms of metal induced asthma remain unclear. The role of immediate and delayed type of allergy (and/or other mechanisms, such as immunotoxical) in metal-induced asthma has not been definitely clarified.

The aim of this study was to evaluate the coexisting factors and usefulness of diagnostic methods in metal-induced asthma in Polish welders.

\section{MATERIALS AND METHODS}

\section{Study groups}

Study group comprised:

- Group A - 50 welders, occupationally exposed to metals with suspicion of metal-induced occupational asthma, admitted to Department of Occupational Diseases and Toxicology, Nofer Institute of Occupational Medicine, Łódź, Poland). Most of these patients were treated with typical anti-asthmatic medication (inhaled glucocorticosteroids, $\beta_{2}$ mimetics).

- Group B - 100 welders, occupationally exposed to metals without suspicion of metal-induced occupational asthma, working in factories in region of Łódź,

- Group C and D - without a history of occupational exposure to metals (10 patients with atopic asthma and 10 healthy subjects).

All subjects were male, using different methods of welding, and exposed to different kind of occupational allergens, including metals, isocyanates, acid anhydrides, colophony. In our study we focused only on allergy to metals.
Therefore, we did not perform any tests for allergy to other occupational allergens than metals.

The study protocol was approved by the local Biomedical Ethics Committee.

\section{Methods}

Questionnaire

Each subject had a medical history collected to gain information on the history of atopy, occupational exposure, respiratory symptoms, and the smoking status.

Occupational asthma was suspected among subjects who reported a positive history of asthmatic symptoms (dyspnoea, cough) at the workplace.

Clinical examination was also performed in all subjects.

\section{Skin prick tests}

Skin prick tests (SPT) were performed in all examined groups (in exposed welders and in control subjects) on the volar part of the forearm with common and occupational allergens. Common allergens included tree and grass pollens, Dermatophagoides pteronyssinus, Dermatophagoides farinae, moulds, feathers (Allergopharma, Germany); occupational allergens included $0.1 \%$ and $0.01 \%$ aqueous solutions of metal salts (nickel $-\mathrm{Ni}\left(\mathrm{NO}_{3}\right)_{2}$, chromium - $\mathrm{CrCl}_{3}$, cobalt - $\mathrm{Co}\left(\mathrm{NO}_{3}\right)_{2}$, vanadium $\mathrm{NH}_{4} \mathrm{VO}_{3}$, zinc $-\mathrm{Zn}\left(\mathrm{NO}_{3}\right)_{2}$, manganese $-\mathrm{MnCl}_{2}$, cadmium - $\mathrm{Cd}\left(\mathrm{NO}_{3}\right)_{2}$ - Physicochemical Unit, Warszawa, Poland). The SPTs were performed according to standardized techniques [12] and assessed after 15 min. Positive reaction was defined as a wheal diameter of at least $3 \mathrm{~mm}$ in the absence of reaction to the diluent and in the presence of a positive reaction to histamine.

Pulmonary function and metacholine challenge testing Resting spirometry (Jaeger Master Scope Spirometer VIASYS Healthcare, Germany) was performed in all subjects (reference values for Caucasian population according 
to European Respiratory Society - ERS). Metacholine challenge was performed only in subjects from group A according to Cockcroft before and $24 \mathrm{~h}$ after the test [13].

\section{X-rays}

Chest X-ray was performed in all subjects. Pulmonary $\mathrm{X}$-ray changes were classified as: nodular changes, interstitial fibrosis, and other changes. The reading of the radiographs was blinded for the reader.

Specific inhalation challenge tests

They were performed:

- In group A - with metals reported by the patient as suspected trigger factor in flow nebulizer (temp. $22-25^{\circ} \mathrm{C}$, time $5 \mathrm{~min}, 0.1 \%$ aqueous solution of nickel, chromium, cobalt or manganese salts - the same as those used for SPT). One day prior to provocation, the placebo test was conducted (isotonic saline solution). Before challenge testing these welders remained out of exposure for 15-30 days.

- In group B - in 17 subjects reporting symptoms of dyspnoea, the challenge was performed at the workplace during normal day of welding.

- In groups $\mathrm{C}$ and $\mathrm{D}$ (control groups) - challenge with the same metals (with nickel, chromium, and cobalt in 3 persons from group $\mathrm{C}$ and in 3 persons from group $\mathrm{D}$, with manganese in 1 person from group $\mathrm{C}$ and 1 from group D), was performed in the same conditions.

During inhalation challenge tests, bronchial response was measured by serial monitoring of forced expiratory volume in $1 \mathrm{~s}\left(\mathrm{FEV}_{1}\right)$ and peak expiratory flow rate (PEFR) before and $5 \mathrm{~min}, 30 \mathrm{~min}, 1 \mathrm{~h}, 2 \mathrm{~h}, 4 \mathrm{~h}, 6 \mathrm{~h}$, and $24 \mathrm{~h}$ after the provocation.

The administration of anti-asthmatic medications was stopped before the challenge tests according to common standards (inhaled glicocorticosteroids -5 days, $\beta_{2}$ mimetics - 2 days before the challenge).
Induced sputum analysis

Cellular and biochemical profiles of induced sputum (ISP) were analysed in 50 patients from group $\mathrm{A}$, in 17 patients from group $\mathrm{B}$, and in all subjects from group $\mathrm{C}$ and $\mathrm{D}$. ISP was collected before and $24 \mathrm{~h}$ after allergen exposure with use of hypertonic saline. The whole process of collecting ISP has been described elsewhere [14].

Diagnostic criteria of occupational asthma Diagnosis of occupational asthma was based on positive response to the provocation test/workplace test, i.e. reporting work-related chest symptoms for which inhalation challenge test induced an asthmatic reaction (at least a $20 \%$ decrease in $\mathrm{FEV}_{1}$ ) or a three-fold increase in non-specific bronchial hyperreactivity $\left(\mathrm{PC}_{20}\right)$ and increase in eosinophils proportion in induced sputum persisting up to $24 \mathrm{~h}$ after the provocation and when a two-fold increase in these parameters was observed; the cut off point for the test was at least $3 \%$ of eosinophils after the test [15].

\section{Statistical analysis}

To evaluate the risk factor for lung X-ray changes, obstructive pattern in spirometry and for a positive challenge test with metals, the relative risk (RR) values and 95\% confidence intervals were calculated with SigmaStat11 software. The analysis included group A and group B. All determined factors were also introduced to the multiple logistic regression model covering all factors determined in relative risk description (SigmaStat11).

\section{RESULTS}

The characteristics of the study groups and the results of spirometry are shown in Table 1.

Results of inhalation challenge tests in group A (welders with suspicion of metal-induced occupational asthma) are presented in Table 2. 
Table 1. Characteristics of study groups and rest spirometry results

\begin{tabular}{|c|c|c|c|c|}
\hline \multirow{2}{*}{ Characteristics } & \multicolumn{4}{|c|}{ Study groups } \\
\hline & $\mathrm{A}(\mathrm{N}=50)$ & $\mathrm{B}(\mathrm{N}=100)$ & $\mathrm{C}(\mathrm{N}=10)$ & $\mathrm{D}(\mathrm{N}=10)$ \\
\hline Mean age $( \pm S D)$ & $49.18 \pm 8.48$ & $45.14 \pm 6.74$ & $42.86 \pm 7.12$ & $45.12 \pm 12.23$ \\
\hline History of atopy, n (\%) & $5(10)$ & $38(38)$ & $10(100)$ & 0 \\
\hline $\begin{array}{l}\text { Smokers and ex smokers } \\
(20 \text { pack a year or } \\
\text { more), } \mathrm{n}(\%)\end{array}$ & $38(76)$ & $52(52)$ & $2(20)$ & $1(10)$ \\
\hline $\begin{array}{l}\mathrm{FEV}_{1} \% \text { predicted value } \\
\quad(\text { mean } \pm \mathrm{SD})^{*}\end{array}$ & $77.65 \pm 24.81$ & $94.4 \pm 13.23$ & $89.16 \pm 9.23$ & $101.44 \pm 17.35$ \\
\hline $\begin{array}{l}\text { FVC \% predicted value } \\
\quad(\text { mean } \pm \mathrm{SD})^{* *}\end{array}$ & $88.67 \pm 14.67$ & $94.41 \pm 13.23$ & $91.56 \pm 8.33$ & $103.12 \pm 16.11$ \\
\hline $\mathrm{FEV}_{1} / \mathrm{FVC}^{* * *}$ & $72.10 \pm 7.60$ & $75.80 \pm 7.10$ & $73.50 \pm 4.10$ & $77.40 \pm 6.60$ \\
\hline $\begin{array}{l}\text { Subjects with obstructive } \\
\text { pattern, } \mathrm{n}(\%)\end{array}$ & $19(38)$ & $10(10)$ & $3(30)$ & 0 \\
\hline
\end{tabular}

Mann-Whitney rank sum test results:

* Group A vs. B - p < 0.05, group A vs. C and B vs. C - no significant differences,

** Group A vs. B $-\mathrm{p}<0.05$, group A vs. C and B vs. C - no significant differences,

*** Group A vs. C and group B vs. C - p < 0.05, group A vs. B - no significant differences.

Positive results of specific inhalation challenge tests with metals were obtained in 9 cases ( 3 cases with nickel, 4 with chromium, 1 with cobalt and 1 case with manganese).

In all patients of group $\mathrm{A}$, the placebo test (nebulization with $1 \%$ sol. of potassium chloride) did not reveal any changes in clinical symptoms, spirometry or cell proportion in induced sputum.

In group B (welders without suspicion of occupational asthma) workplace challenge tests (during 8 hours of work shift) were performed in 17 subjects (in all with history of work-related respiratory symptoms). Only in one case we observed positive result of this test (clinical symptoms and spirometry changes of bronchial constriction, significant increase in eosinophils proportion in induced sputum).

Based on the results, 9 cases of occupational asthma were diagnosed in group A and 1 case in group B. Detailed results in cases in which challenge tests were positive are presented in Table 3. In all ten cases FEV $_{1}$ fell more than $20 \%$. Additionally, in some cases there was a three-fold increase in methacholine $\mathrm{PC}_{20}$ and in many cases a two-fold increase to at least $3 \%$ of eosinophils was observed.

In control groups ( $\mathrm{C}$ and $\mathrm{D}$ ) we didn't observe any changes in clinical, spirometry or induced sputum parameters during inhalation tests with metals.

We did not confirm negative challenge test results with workplace challenge test because of technical problems

Table 2. Results of inhalation challenge tests in group A $(\mathrm{N}=50)$

\begin{tabular}{lcc}
\hline $\begin{array}{c}\text { Inhalation } \\
\text { challenge test } \\
\text { with: }\end{array}$ & $\begin{array}{c}\text { Subjects* } \\
\text { (n) }\end{array}$ & $\begin{array}{c}\text { Positive results (occupational } \\
\text { asthma recognition) } \\
\text { (n) }\end{array}$ \\
\hline Nickel & 20 & 3 \\
Chromium & 32 & 4 \\
Cobalt & 5 & 1 \\
Manganese & 1 & 1 \\
\hline
\end{tabular}

* In 8 subjects, suggesting that nickel and chromium are symptoms trigger, inhalation challenge tests were performed with both metals (with nickel and, 7 days after, with chromium). None of these subjects had positive result of challenge test with either of those metals. 
Table 3. Results in cases where challenge tests were positive

\begin{tabular}{|c|c|c|c|c|c|c|c|c|}
\hline \multirow[t]{2}{*}{ Patient } & \multirow[t]{2}{*}{$\begin{array}{l}\text { Challenge } \\
\text { test with: }\end{array}$} & \multirow{2}{*}{$\begin{array}{c}\downarrow \mathrm{FEV}_{1} \geq 20 \% \\
\text { during test/ } \\
\text { type of } \\
\text { reaction }\end{array}$} & \multirow[t]{2}{*}{$\begin{array}{l}\text { Positive SPT } \\
\text { with: }\end{array}$} & \multicolumn{2}{|c|}{$\begin{array}{c}\mathrm{PC}_{20} \text { of metacholine } \\
(\mathrm{mg} / \mathrm{ml})\end{array}$} & \multicolumn{2}{|c|}{$\begin{array}{c}\text { Eosinophil } \\
\text { in induced sputum } \\
(\%)\end{array}$} & \multirow[t]{2}{*}{ Recognition } \\
\hline & & & & before test & after test & before test & after test & \\
\hline 1 (group A) & $\mathrm{Ni}$ & +/late & $\mathrm{Ni}$ & 3.2 & 1.1 & 1 & 2 & occupational asthma \\
\hline 2 (group A) & $\mathrm{Ni}$ & +/late & $\mathrm{Ni}$ & 7.4 & 3.3 & 0 & 2 & occupational asthma \\
\hline 3 (group A) & $\mathrm{Ni}$ & $+/$ dual & V & 11.2 & 3.7 & 2 & 4 & occupational asthma \\
\hline 4 (group A) & $\mathrm{Cr}$ & +/late & - & 1.2 & 0.8 & 2 & 5 & occupational asthma \\
\hline 5 (group A) & $\mathrm{Cr}$ & + late & - & 8.8 & 2.5 & 1 & 3 & occupational asthma \\
\hline 6 (group A) & $\mathrm{Cr}$ & $+/$ dual & $\mathrm{Ni}$ & 0.6 & nd & 0 & 3 & occupational asthma \\
\hline 7 (group A) & $\mathrm{Cr}$ & +/late & V & 9.8 & 3.3 & 3 & 8 & occupational asthma \\
\hline 8 (group A) & Co & +/late & Co & 2.4 & 1.2 & 1 & 4 & occupational asthma \\
\hline 9 (group A) & $\mathrm{Mn}$ & + late & - & 0.5 & nd & 0 & 8 & occupational asthma \\
\hline 10 (group B) & $\begin{array}{l}\text { workplace } \\
\text { challenge }\end{array}$ & + late & Co & nd & nd & 2 & 5 & occupational asthma \\
\hline
\end{tabular}

$\mathrm{Ni}$ - nickel, $\mathrm{Cr}$ - chromium, $\mathrm{Co}$ - kobalt, $\mathrm{Mn}$ - manganese, $\mathrm{V}$ - vanadium. nd - not done.

(workplaces closed throughout the whole of Poland) and because of the fact that exposure to other allergens was not relevant for this study.

Results of skin prick tests with common aeroallergens and metals (nickel, chromium, cobalt, vanadium) in groups $A$ and B are shown in Table 4. SPT results with other studied metals (zinc, manganese, cadmium) were negative.

Table 4. Number of positive results of skin prick tests with common aeroallergens and metal salts

$\left.\begin{array}{lcc}\hline \text { Allergens } & \begin{array}{c}\text { Subjects with } \\ \text { recognized } \\ \text { occupational } \\ \text { asthma } \\ (\mathrm{N}=10) \\ \mathrm{n}(\%)\end{array} & \begin{array}{c}\text { Subjects without recognized } \\ \text { occupational asthma } \\ (\mathrm{N}=140)\end{array} \\ \mathrm{n}(\%)\end{array}\right)$

Skin prick tests with common aeroallergens were positive in six patients with occupational asthma. The positive results of skin prick tests with metals (nickel, cobalt, vanadium) were found in seven subjects out of the ten in whom occupational asthma due to metals was confirmed by positive result of inhalation challenge test or workplace challenge test. In seven subjects without occupational asthma we also obtained positive results of SPT with metals. In groups $\mathrm{C}$ and $\mathrm{D}$, skin prick tests with metals were negative. In group $C$ in all subjects we observed positive results of SPT with common aeroallergens. In group D, SPT with common aeroallergens was negative.

In $94(62 \%)$ of examined welders, pulmonary changes in chest $X$-ray were recognized. Nodular changes were found in 39 persons and/or interstitial fibrosis was detected in 61 persons. Only 56 of welders had normal chest X-ray; however, all patients with recognized occupational asthma due to metals had no changes in X-ray examination. In both control groups the results of $\mathrm{X}$-ray examinations were normal in all subjects. 
Table 5. Statistical analysis of factors coexisting with the presence of chest X-ray changes (p- or q-type nodular changes, interstitial changes) in group of 150 welders

\begin{tabular}{|c|c|c|c|c|c|c|}
\hline \multirow[t]{2}{*}{ Factor } & \multicolumn{2}{|c|}{$\begin{array}{l}\text { Welders with X-ray } \\
\text { changes } \\
(\mathrm{N}=94)\end{array}$} & \multicolumn{2}{|c|}{$\begin{array}{l}\text { Welders without } \\
\text { X-ray changes } \\
(\mathrm{N}=56)\end{array}$} & \multirow[t]{2}{*}{ RR (CI 95\%) } & \multirow[t]{2}{*}{$\mathrm{p}$} \\
\hline & $\mathrm{n}$ & $\%$ & $\mathrm{n}$ & $\%$ & & \\
\hline Smoking (present and ex-smokers*) & 56 & 59.6 & 34 & 60.7 & $0.98(0.76-1.26)$ & 0.973 \\
\hline Working as a welder for more than 10 years & 39 & 41.5 & 9 & 16.0 & $1.51(1.2-1.89)$ & 0.002 \\
\hline Positive results of skin prick tests with common aeroallergens & 21 & 22.3 & 13 & 23.2 & $0.98(0.72-1.32)$ & 0.938 \\
\hline Positive results of skin prick tests with metal salts & 7 & 7.4 & 7 & 12.5 & $1.28(0.75-2.19)$ & 0.46 \\
\hline Recognition of occupational asthma & 5 & 5.3 & 5 & 8.9 & $1.27(0.68-2.39)$ & 0.604 \\
\hline Obstructive pattern of spirometry & 17 & 18.0 & 12 & 21.4 & $0.92(0.66-1.29)$ & 0.773 \\
\hline
\end{tabular}

$\mathrm{RR}$ - relative risk, CI - confidence interval.

* Ex-smokers with history of smoking for more than 20 pack a year.

Table 6. Statistical analysis of factors coexisting with the presence of obstructive pattern of spirometry in group of 150 welders

\begin{tabular}{|c|c|c|c|c|c|c|}
\hline \multirow[t]{2}{*}{ Factor } & \multicolumn{2}{|c|}{$\begin{array}{l}\text { Welders with } \\
\text { obstruction } \\
(\mathrm{N}=29)\end{array}$} & \multicolumn{2}{|c|}{$\begin{array}{l}\text { Welders without } \\
\text { obstruction } \\
(\mathrm{N}=121)\end{array}$} & \multirow[t]{2}{*}{ RR (CI 95\%) } & \multirow[t]{2}{*}{$\mathrm{p}$} \\
\hline & $\mathrm{n}$ & $\%$ & $\mathrm{n}$ & $\%$ & & \\
\hline Smoking (present and ex-smokers*) & 24 & 82.7 & 66 & 54.5 & $3.20(1.29-7.92)$ & 0.010 \\
\hline Working as a welder for more than 10 years & 10 & 34.5 & 38 & 31.4 & $1.12(0.56-2.22)$ & 0.922 \\
\hline Positive results of skin prick tests with common aeroallergens & 6 & 20.7 & 28 & 23.1 & $0.89(0.39-2.01)$ & 0.971 \\
\hline Positive results of skin prick tests with metal salts & 3 & 10.3 & 11 & 9.0 & $0.89(0.31-2.58)$ & 0.883 \\
\hline
\end{tabular}

* Ex-smokers with history of smoking for more than 20 pack a year.

Abbreviations as in Table 5.

Table 7. Statistical analysis of factors coexisting with the recognition of occupational asthma in group of 150 welders

\begin{tabular}{|c|c|c|c|c|c|c|}
\hline \multirow[t]{2}{*}{ Factor } & \multicolumn{2}{|c|}{$\begin{array}{c}\text { Welders with } \\
\text { occupational } \\
\text { asthma } \\
(\mathrm{N}=10)\end{array}$} & \multicolumn{2}{|c|}{$\begin{array}{c}\text { Welders without } \\
\text { occupational } \\
\text { asthma } \\
(\mathrm{N}=140)\end{array}$} & \multirow[t]{2}{*}{ RR (CI 95\%) } & \multirow[t]{2}{*}{$\mathrm{p}$} \\
\hline & $\mathrm{n}$ & $\%$ & $\mathrm{n}$ & $\%$ & & \\
\hline 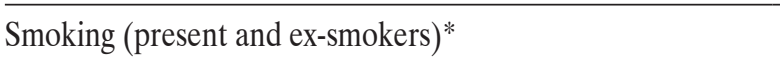 & 9 & 90 & 81 & 57.9 & $0.91(0.85-0.99)^{* *}$ & 0.095 \\
\hline Working as a welder for more than 10 years & 6 & 60 & 42 & 30.0 & $0.91(0.81-1.02)$ & 0.107 \\
\hline Positive results of skin prick tests with common aeroallergens & 6 & 60 & 28 & 20.0 & $0.85(0.73-1.0)$ & 0.010 \\
\hline Positive results of skin prick tests with metal salts & 7 & 70 & 7 & 5.0 & $1.96(1.16-3.3)$ & $<0.001$ \\
\hline
\end{tabular}

Abbreviations as in Table 5.

* Ex-smokers with history of smoking for more than 20 pack a year.

** Factor not confirmed in multiple logistic regression model. 
Table 8. Multiple logistic regression models of determined risk factors

\begin{tabular}{lcr}
\hline \multicolumn{1}{c}{ Regression model } & OR (CI 95\%) & p \\
\hline Chest X-ray changes vs. working for more than 10 years as welder & $4.56(1.89-11.05)$ & $<0.001$ \\
Obstructive pattern of spirometry vs. smoking & $4.03(1.44-11.28)$ & 0.008 \\
Occupational asthma vs. positive SPT with metal salts & $39.88(5.79-274.49)$ & $<0.001$ \\
Occupational asthma vs. smoking & $11.27(0.98-129.96)$ & 0.052 \\
Occupational asthma vs. positive SPT with common aeroalergens & $1.86(0.29-12.03)$ & 0.513 \\
\hline
\end{tabular}

SPT - skin prick tests, OR - odds ratio, CI - confidence interval.

Results of statistical analysis are presented in Tables 5-8. The statistical analysis revealed that working as a welder for more than 10 years was the coexisting factor of presence of chest X-ray changes ( $\mathrm{p}$ - or q-type nodular changes or interstitial changes). Smoking was the coexisting factor of presence of obstructive pattern of spirometry. Positive results of skin prick tests with metals were the coexisting factors of occupational asthma due to metals among welders. All coexisting factors were confirmed as statistically significant with multiple logistic regression model.

\section{DISCUSSION}

Occupational allergic asthma is caused by the inhalation of specific sensitizing agents in the workplace. This type of asthma may develop as a consequence of exposure to certain types of welding fumes [16]. It is known that welding can cause asthma, as described in several case reports. Meredith [17] evaluated new cases of asthma reported for all occupations during 1989 and 1990. Twenty three cases $(2.1 \%)$ of occupational asthma were identified in workers exposed to welding fumes. Asthma was diagnosed in 124 of 246 new cases of occupational lung diseases in welders reported by Ross et al. [18]. According to Beach et al. [19], approximately $1 \%$ of welders were likely to develop occupational asthma after 5 years of work. Most studies estimated 2-3.2\% of all cases of occupational asthma as welding related asthma. Exposure to metals (nickel, chromium, cobalt, etc.) released during the welding process can be the cause of occupational asthma (inhalation exposure to these allergens should be treated as occupational, therefore contact exposure to nickel and chromium may be common). Metals are probably one of the most important allergens for welders. Thus far, all metallic elements that cause asthma can be classified within the main "transition metal" series, in the group III metal series of the periodic table of elements. However, the pathogenesis, risk factors and natural history of occupational asthma due to metals in welders remain still unknown.

The role of allergen-specific $\operatorname{IgE}$ (as $\operatorname{IgE}$ ) antibodies in allergy to metals is unclear. $\operatorname{IgE}$ specific to some metals (nickel, chromium, cobalt, platinum) have been identified, but their role in pathogenesis of metal induced asthma was not fully confirmed. The role of other mechanisms, i.e. late type allergic reaction and/or immunotoxic mechanisms have not been excluded. However, in our group of welders with occupational asthma confirmed by inhalation challenge test, positive results of skin prick tests SPT (identifying as IgE) to metals were found in seven subjects (70\%). Statistical analysis revealed that positive results of SPT with metals are the coexisting factors of occupational asthma due to metals in this group. On the other hand, in seven subjects without occupational asthma we also obtained positive results of SPT with metals. Therefore, laboratory findings aimed at identification of as IgE seem to be insufficient for diagnosing of occupational asthma due to metals. In the majority of previous 
studies, atopy was not described as a risk factor of metal asthma. In our group of welders, the positive results of skin prick tests with common aeroallergens were obtained in six $(60 \%)$ out of ten patients with recognized occupational asthma. The frequency of positive results of SPT with common aeroallegens in examined welders was similar to that in the general population.

Our observations confirmed the key role of specific inhalation challenge tests in diagnosing of metal-induced occupational asthma. In 9 cases, nebulization with metal solution induced characteristic clinical and spirometry changes (with the presence of late allergy reaction in all cases). The results were confirmed by allergen-induced inflammatory reaction in the airways (significant increase in the number and proportion of eosinophils in induced sputum). In one case we observed positive reaction during workplace test. The placebo tests and the tests in control groups were negative, which made it possible to exclude the non-specific reactions. Although the control groups were not numerous, they were sufficient for the analysis of the results.

In one welder from group B (without suspicion of occupational asthma) during workplace test we observed an increase of eosinophils proportion in induced sputum from $2 \%$ to $4 \%$ without clinical and spirometry changes and without subjective symptoms of dyspnoea. In this case eosinophilic bronchitis without asthma was suspected. This condition has not been described yet as a consequence of occupational exposure to metals. We also identified the first well documented case of manganese-induced occupational asthma, which was described elsewhere [20]. In many studies [21-30] an excess decline in pulmonary function in groups of welders over periods of occupational exposure and presence of pulmonary changes was described. The interesting observation were also pulmonary changes in chest X-ray in the study group. Other authors described the presence of interstitial fibrosis or nodular changes in welders caused by some metals (hard metal disease, berylliosis), toxic pneumonitis, pneumoconiosis (asbestos, silicosis) but the high frequency of these changes in the group of Polish welders, especially among those without suspicion of occupational respiratory disease, was an unexpected finding. Statistical analysis revealed that working as a welder for more than 10 years was the coexisting factor of presence of chest $\mathrm{X}$-ray changes ( $\mathrm{p}$ - or q-type nodular changes or interstitial changes).

It may be concluded that specific inhalation challenge plays the key role in diagnostics of metal-induced occupational asthma in welders. Additionally, the high prevalence of interstitial pulmonary changes in chest X-ray in examined welders (also without suspicion of airway disease) is the important issue for occupational safety and health services, calling for steps intended to improve prophylaxis.

\section{REFERENCES}

1. Antonini JM. Health Effects of Welding. Crit Rev Toxicol 2003;33:61-103.

2. Bernstein IL, Merget R. Metals. In: Bernstein IL, ChanYeung M, Malo JL, Bernstein D. Asthma in the workplace. 3rd edition. New York London: Taylor\&Francis; 2006.

3. Muñoz X, Cruz MJ, Freixa A, Guardino X, Morell F. Occupational Asthma Caused by Metal Arc Welding of Iron. Respiration 2009;78:455-9.

4. Antonini JM, Taylor MD, Zimmer AT, Roberts JR. Pulmonary responses to welding fumes: role of metal constituents. J Toxicol Environ Health 2004;67:233-49.

5. Mapel D, Coultas D. Disorders due to minerals other than silica, coal, and asbestos, and to metals. In: Hendrick DJ, Burge PS, Beckett WS, Churg A. Occupational Disorders of the Lung. Recognition, Management, and Prevention. London: W.B. Saunders; 2002.

6. Christensen SW, Bonde JP, Omland O. A prospective study of decline in lung function in relation to welding emissions. J Occup Med Toxicol 2008;26:3-6. 
7. Hannu T, Piipari R, Tuppurainen M, Nordman H, Tuomi T. Occupational asthma caused by stainless steel welding fumes: a clinical study. Eur Respir J 2007;29:85-90.

8. Hannu T, Piipari R, Kasurinen H, Keskinen H, Tuppurainen M, Tuomi T. Occupational asthma due to manual metal-arc welding of special stainless steels. Eur Respir J 2005;26:736-9.

9. Temel O, Sakar Coşkun A, Yaman N, Sarioğlu N, Alkaç C, Konyar I, et al. Occupational asthma in welders and painters. Tuberk Toraks 2010;58:64-70.

10. Malo JL. Occupational rhinitis and asthma due to metal salts. Allergy 2005;60:138-9.

11. Vendenplas O, Dargent F, Auveerdin JJ. Occupational asthma due to gas metal arc welding on mild steel. Tho$\operatorname{rax} 1995 ; 50: 587-8$.

12. Dreborg S, Frew AJ, editors. Allergen standardization and skin tests. Allergy 1993;48 Suppl. 14: 49-82.

13. Cockcroft DW, Killian DN, Mellon JJ, Hargreave FE. Bronchial reactivity to histamine: a method and clinical survey. Clin Allergy 1977;7:235-43.

14. Krakowiak A, Krawczyk-Adamus P, Dudek W, Walusiak J, Palczynski C. Changes in cellular and biochemical profiles of induced sputum after allergen-induced asthmatic response: method for studying occupational allergic airway inflammation. Int J Occup Med Environ Health 2005;18:27-33.

15. Quirce S, Lemiere C, de Blay F, del Pozo V, Gerth Van Wijk R, Maestrelli P, et al. Nonivasive methods for assessment of airway inflammation in occupational settings. Allergy 2010;65:445-58.

16. Lillienberg L, Zock JP, Kromhout H, Plana E, Jarvis D, Torén $\mathrm{K}$, et al. A population-based study on welding exposures at work and respiratory symptoms. Ann Occup Hyg 2008;52:107-115.

17. Meredith S. Reported incidence of occupational asthma in the United Kingdom, 1989-90. J Epidemiol Community Health 1993;47:459-63.

18. Ross D.J, Keynes H.L, McDonald J.C. SWORD'97: surveillance of work-related and occupational respiratory disease in the UK. Occup Med 1998;48:481-5.
19. Beach JR, Dennis JH, Avery AJ. An epidemiologic investigation of asthma in welders. Am J Respir Crit Care Med 1996;154:1394-400.

20. Wittczak T, Dudek W, Krakowiak A, Walusiak J, PałczyńskiC. Occupational asthma due to manganese exposure: a case report. Int J Occup Med Environ Health 2008;21(1):81-3. DOI 10.2478/v10001-007-0041-1.

21. Bradshaw LM, Fishwick D, Slater T, Pearce N. Chronic bronchitis, work related respiratory symptoms and pulmonary function in welders in New Zealand. Occup Environ Med 1998;55:150-4.

22. Chinn DJ, Cotes JE, El Gamal FM, Wollaston JF. Respiratory health of young shipyard welders and other tradesmen studied cross sectionally and longitudinally. Occup Environ Med 1995;55:33-42.

23. El-Zein M, Malo JL, Infante-Rivard C, Gautrin D. Prevalence and association of welding related systemic and respiratory symptoms in welders. Occup Environ Med 2003;60: 655-61.

24. Huvinen M, Uitti J, Oksa P, Palmroos P, Laippala P. Respiratory health effects of long-term exposure to different chromium species in stainless steel production. Occup Med 2002;52: 203-12. 25. Jafari AJ, Assari M. Respiratory Effect from Work-Related Exposure to Welding Fumes in Hamadan, Iran. Arc Environ Health 2004;59:116-20.

26. Lyngenbo O, Groth S, Groth M: Occupational lung function impairment in never-smoking Danish welders. Scand J Soc Med 1989;17:157-64.

27. McMillan G, Welding W, Hendrick DJ, Burge PS, Beckett WS, Churg A. Occupational Disorders of the Lung. Recognition, Management, and Prevention. London: W.B. Saunders; 2002.

28. Meo SA, Azeem MA, Subhan MM. Lung function in Pakistani welding workers. J Occup Environ Med 2003;45: 1068-73.

29. Oxhoj H, Bake B, Wedel H, Wilhelmsen L. Effects of Electric Arc Welding on Ventilatory Lung Function. Arch Environ Health 1979;30:211-6.

30. Wang ZP, Larsson K, Malmberg P, Sjorgen B, Hallberg BO, Wrangskog K.Asthma, lungfunction, and bronchial responsiveness in welders. Am J Ind Med 1994;26:741-54.

This work is available in Open Access model and licensed under a Creative Commons Attribution-NonCommercial 3.0 Poland License - http://creativecommons.org/ licenses/by-nc/3.0/pl/deed.en. 